\title{
MACROPHYTE VEGETATION OF ARTIFICIAL WATER RESERVOIRS IN THE KRUPINSKÁ PLANINA MTS., INCLUDING THE FIRST RECORD OF POTAMETUM ACUTIFOLII FROM SLOVAKIA
}

\author{
Richard HRIVNÁK*
}

\begin{abstract}
Research of macrophyte vegetation of the artificial water reservoirs was carried out during the vegetation season of 2008 in the Krupinská planina Mts. (southern part of central Slovakia). Twenty-one reservoirs were studied and twenty plant communities from the Lemnetea, Potametea and Phragmito-Magnocaricetea classes were found. Potametum acutifolii is a new aquatic community for the territory of Slovakia that was found in the reservoir near Hrušov village in intermediately deep, slightly alkaline water with a relatively low content of soluble mineral matters, a high water transparency and a silt-clay sediment on the bottom. Moisture was the main environmental gradient of the studied vegetation explained by Ellenberg's indicator values. Species richness was significantly negatively correlated with water depth. The correlation between the area of reservoirs and the number of detected plant communities was weak and non-significant. Changes of macrophyte vegetation were studied on the case of three reservoirs. Detected changes were caused mainly by human activities or water level fluctuations within the studied period.
\end{abstract}

Key words: aquatic and marsh vegetation, plant community changes, ecology, DCA.

\section{Izvleček}

Raziskave makrofitske vegetacije umetnih vodnih smo izvedli v vegetacijski sezoni leta 2008 v hribovju Krupinská planina (južni del osrednje Slovaške). Raziskali smo enaindvajset vodnih teles in našli dvaindvajset rastlinskih združb iz razredov Lemnetea, Potametea in Phragmito-Magnocaricetea. Asociacija Potametum acutifolii je nova vodna rastlinska združba, najdena na ozemlju Slovaške. Našli smo jo v vodnem telesu blizu vasi Hrušov v srednjegloboki, rahlo alkalni vodi z razmeroma nizko vsebnostjo raztopljenih mineralnih snovi, z visoko vodno prepustnostjo in muljasto-glineno usedlino na dnu. Glavni okoljski gradient obravnavane vegetacije, kot kažejo Ellenbergove indikacijske vrednosti, je vlažnost. Število vrste je v negativni odvisnosti z globino vode. Korelacija med površino vodnega telesa in številom najdenih rastlinskih združb je bila nizka in ni bila značilna. Spremembe makrofitske vegetacije smo proučevali v treh vodnih zbiralnikih. Opažene spremembe so posledica predvsem človeških dejavnosti ali nihanja vodnega nivoja v obravnavanem obdobju.

Ključne besede: vodna in močvirna vegetacija, spremembe rastlinske združbe, ekologija, DCA.

\section{INTRODUCTION}

Anthropogenic aquatic habitats as water reservoirs are unique localities in cultural and human-exploited landscape. Their value increases when natural aquatic habitats are destroyed or strongly changed by human acitivities. In that case, they represent substitute habitats for indigenous aquatic and marsh vegetation. In the past, the information about vegetation of artificial aquatic habitats in the teritorry of Slovakia was relatively scarce (e.g. Otahel'ová \& Husák 1992). More intensive research started recently (Hrivnák 1999, Ot́ahel'ová 2005, Jursa \& Otahel'ová 2005, Ot́ahel'ová \& Ot́ahel' 2006). Until this period, research activities of botanists had been concentrated on natural aquatic habitats with stagnant water (e.g. river oxbows or natural flooded terrain depressions), which are situated in the val-

\footnotetext{
* Institute of Botany, Slovak Academy of Sciences, Dúbravská cesta 14, SK-845 23 Bratislava, Slovakia; e-mail: richard. hrivnak@savba.sk
} 
leys of bigger rivers such as the Danube, Morava or Latorica (e.g. Šomšák 1963, Ot'ahel'ová 1980, Ot́ahel'ová \& Husák 1982, Otahel'ová \& al. 1994). In general, research of aquatic and marsh vegetation was concentrated into areas with its optimum occurrence, i.e. mainly lowlands and uplands of southern and south-eastern parts of Slovakia. Altitudinally higher and more northern areas have been neglected for a relatively long time. Similarly, research of artificial aquatic habitats started in the last years and data from several Carpathian basins and mountains were published (e.g. Hrivnák 2002a, Hrivnák \& al. 2004, Hrivnák \& Kochjarová 2008, Ot́ahel'ová \& al. 2008). Krupinská planina Mts. is an interesting region of Slovakia where no hydrobotanical research has yet been performed (Fig. 1). I chose this area for the study of macrophyte vegetation of the artificial water reservoirs from following reasons: 1) the study area is situated on the border of two phytogeographical regions, southern part in the Pannonicum and northern part in the Carpaticum regions (cf. Futák 1980), which reflects mainly different climatic characteristics; 2) there are enough appropriate habitats (artificial water reservoirs) for the study to be relatively representative; 3 ) no complex research of macrophyte vegetation has been done in the study area; 4) there is only limited knowledge on plant communities of artificial water reservoirs from the past, but some of the information available is suitable for a comparison with the results presented in this paper (e.g. Hrivnák 1999; Hrivnák 2002b, 2004). Therefore, the main aim of this work is a complex phytosociological and ecological evaluation of macrophyte vegetation of the artificial water reservoirs in the Krupinská planina Mts., including evaluation within a broader regional context as well as comparison of changes of selected water reservoirs.

\section{STUDY AREA}

Macrophyte vegetation was studied in the Krupinská planina Mts (Fig. 1). The mountain is situated in the southern part of central Slovakia with altitudinal range from the lowland to the submountain level. It is a typical volcanic mountain range formed mainly of andesites. From the hydrological point of view, the study area belongs to the Ipel' river catchment area with the following larger rivers and streams: Krupinica, Litava, Vrbovok, Plachtinský potok and Krtís. A substantial part of

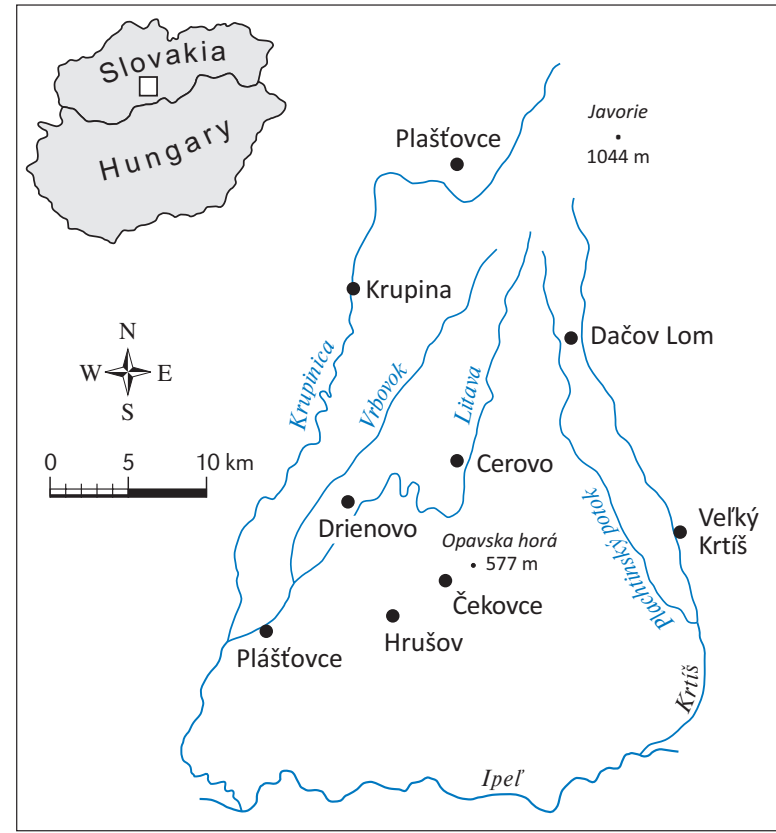

Figure 1: Study sites.

Slika 1: Lokacije preučevanih zbiralnikov.

the area belongs to the warm or moderately warm region with a mean annual air temperature and a precipitation total of 6 to $7^{\circ} \mathrm{C}$ and 600 to $700 \mathrm{~mm}$, respectively (Miklós 2002). Twenty-one artificial water reservoirs with various areas, recent uses and statuses were studied and their characteristics are briefly presented in Table 1 .

\section{METHODS}

Phytosociological relevés were taken according to the Zürich-Montpellier approach. Only stands with at least the minimum areas recommended for this type of vegetation were recorded (Chytrý \& Otýpková 2003). Macrophyte vegetation data were collected in 2008. Fifty-three phytosociological relevés were collected. All the relevés were stored using the TURBOVEG database (Hennekens \& Schaminée 2001) and then exported and processed by the JUICE software (Tichý 2002). Further, they were analysed by TWINSPAN (Hill 1979) with application of the dominance principle. CANOCO 4.5 for Windows package (ter Braak \& Šmilauer 2002) was used for a detrended correspodence analysis (DCA); species percentage data with logarithmic transformation were used and rare species were downweighted. For the ecological interpretation of major gradients 
of the studied wetland vegetation, average nonweighted Ellenberg's indicator values of vascular plant species (Ellenberg \& al. 1992) were plotted onto a DCA ordination diagram as supplementary variables. The associations between some selected environmental and species variables were expressed by Spearmann correlation coeficients using the STATISTICA software (StatSoft 2001). Water reaction and conductivity were measured in selected water reservoirs by $\mathrm{pH}$-meter/conductometer WTW pH/Cond 340i. The position and area of the studied sites was obtained using GPS eTrex Summit fy Garmin and GIS (ArcView programme) from digital orthophotomaps with a resolution of $1 \mathrm{~m}$ to pixel. Data from older papers (Hrivnák 1999; Hrivnák 2002b, 2004) were used for a comparison of diversity and plant communities changes within selected water reservoirs.

The nomenclature of plants follows Marhold and Hindák (1998). The names of vegetation units are presented with author's name and year of description.

\section{RESULTS AND DISCUSSION}

Checklist of vegetation units

Lemnetea O. de Bolós et Masclans 1955

Lemnetalia minoris R. Tx. 1955

Lemnion minoris $\mathrm{R}$. Tx. 1955

Lemno minoris-Spirodeletum polyrhizae

Koch 1954 em. Th. Müller et Görs 1960 (Tab. 2, rels 1-3)

Hydrocharitetalia Rübel 1933

Hydrocharition morsus-ranae Rübel $1933 \mathrm{em}$.

Westhoff et Den Held 1969

Ceratophylletum demersi Hild 1956 (Tab. 2, rel. 4)

Potametea Klika in Klika et Novák 1941

Potametalia Koch 1926

Nymphaeion albae Oberd. 1957

Potametum natantis von Soó 1927 (Tab. 2, rels 7-10)

Polygonetum amphibii von Soó 1927 (Tab. 2 , rels 5-6)

Potametum nodosis Passarge 1964 (Tab. 2, rel. 13)

Potamion pusilli Hejný 1978

Potametum pectinati Carstensen 1955 (Tab.

2 , rel. 15)

Potametum acutifolii Segal 1961 (Tab. 2, rels 11-12)
Potametum trichoidis Tüxen 1974 (Tab. 2, rel. 14)

Phragmito-Magnocaricetea Klika in Klika et Novák 1941

Phragmitetalia Koch 1926

Phragmition australis Koch 1926

Equisetetum fluviatilis Steffen 1931 (Tab. 3, rels 1-2)

Glycerietum aquaticae Hueck 1931 (Tab. 3, rels 3-4)

Phragmitetum vulgaris von Soó 1927 (Tab.

3 , rel. 5)

Scirpetum lacustris Chouard 1924 (Tab. 3, rels 11-12)

Sparganietum erecti Roll 1938 (Tab. 3, rels 6-10)

Typhetum angustifoliae Pignatti 1953 (Tab. 3, rels 13-18)

Typhetum latifoliae Lang 1973 (Tab. 3, rels 19-27)

Magnocaricion elatae Koch 1926

Caricenion gracilis (Neuhäusl 1959) Oberd. et al. 1967

Caricetum vesicariae Chouard 1924 (Tab. 3, rels 28-30)

Phalaridetum arundinaceae Libbert 1931

(Tab. 3, rel. 31)

Nasturtio-Glycerietalia Pignatti 1953

Sparganio-Glycerion Br.-Bl. et Sissing in Boer 1942

Glycerietum fluitantis Eggler 1933 (Tab. 3, rels 32-34)

Leersietum oryzoidis Eggler 1933 (Tab. 3, rels 35-36)

Oenanthetalia aquaticae Hejný in Kopecký et Hejný 1965

Oenanthion aquaticae Hejný ex Neuhäusl 1959

Eleocharitetum palustris Ubrizsy 1948 (Tab. 3, rels 37-38)

\subsection{Phytosociological and ECOLOGIGAL CHARACTERISTICS OF PLANT COMMUNITIES}

Duck-weed vegetation (Lemnetea) was rare in the studied area (Tab. 2). Two associations were found, Lemno minoris-Spirodeletum polyrhizae and Ceratophylletum demersi, the former being more frequent. Stands of Lemno minoris-Spirodeletum polyrhizae grew in small, shallow, eutrophic and silt- 


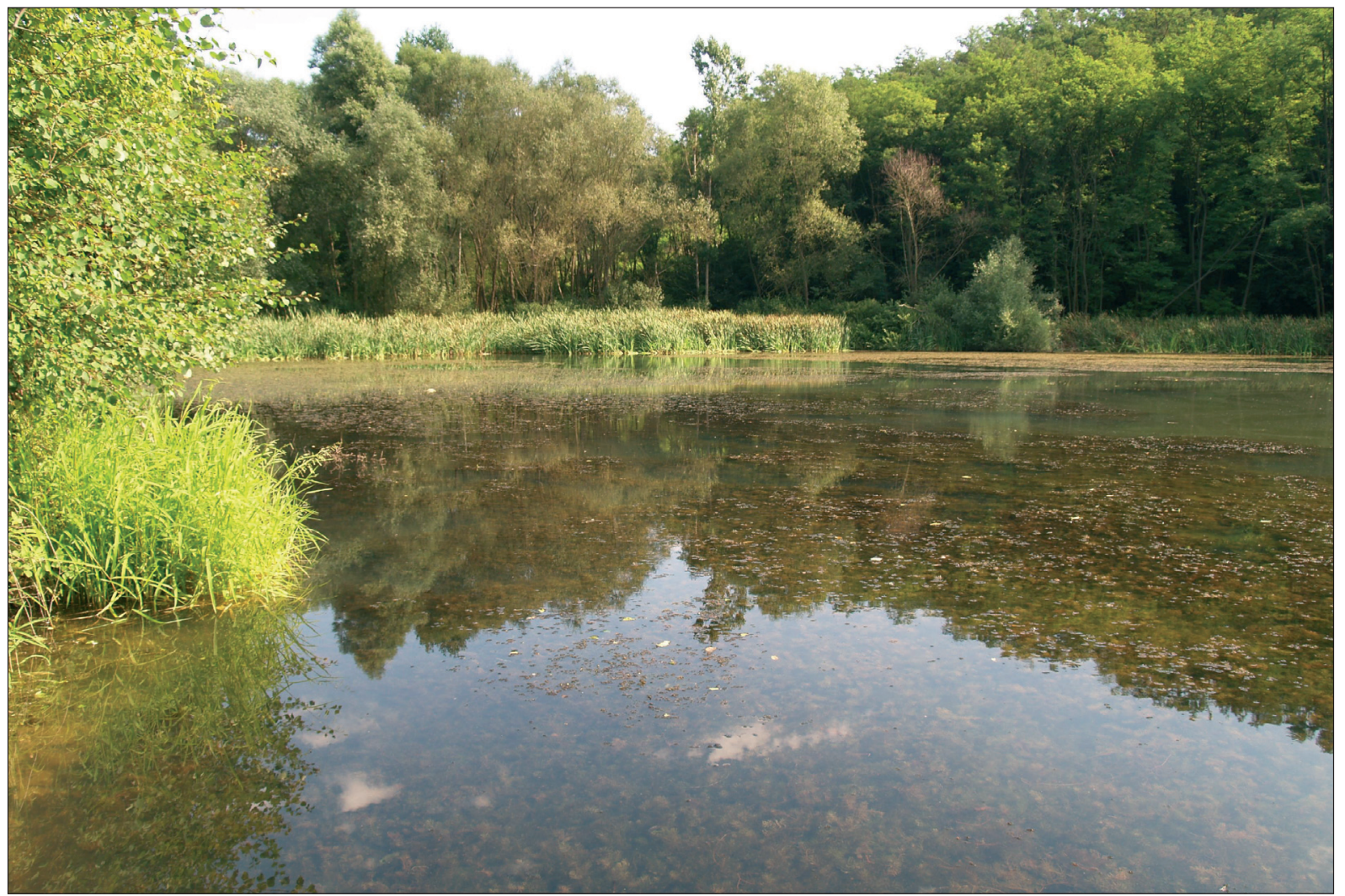

Figure 2: Pláštovce water reservoir. Stands of Ceratophylletum demersi, Leersietum oryzoidis and Typhetum latifoliae in tributary part of reservoir.

Slika 2: Vodni zbiralnik Pláštovce. Sestoji asociacij Ceratophylletum demersi, Leersietum oryzoidis in Typhetum latifoliae v delu zbiralnika s pritoki.

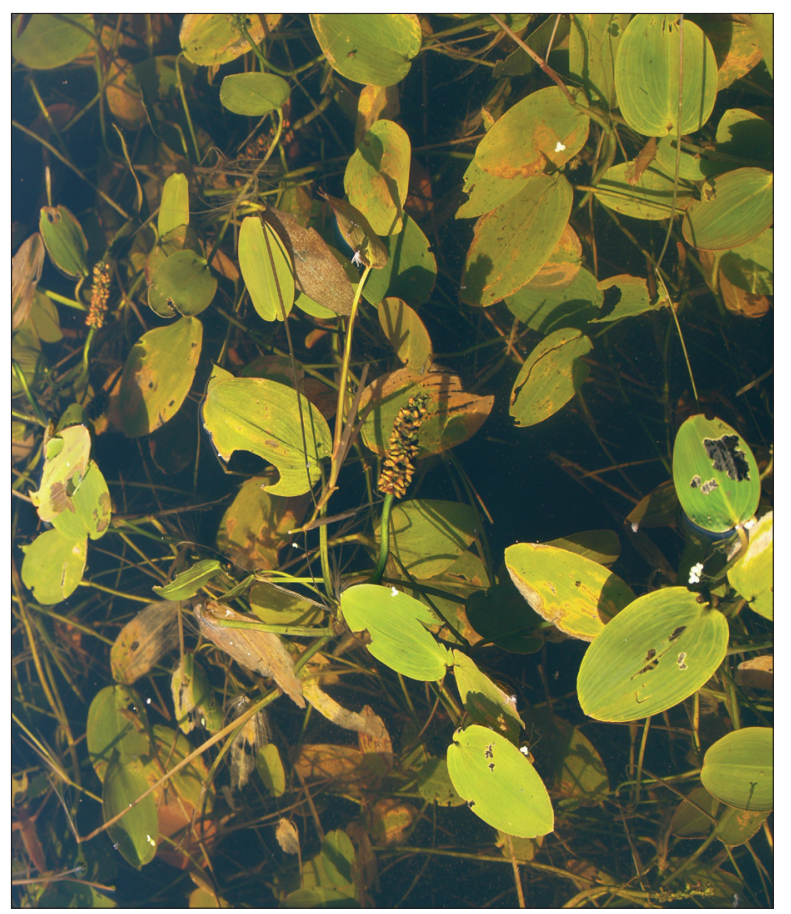

ed reservoirs near human settlements. A similar characteristic is generally typical for this community in various European countries (Schratt 1993, Ot́ahel'ová 1995a, Coldea 1997), although its ecological amplitude is markedly broader (Tomaszewicz 1979, Šumberová 2007). In Slovakia, the occurrence of this community is known mainly from lowlands and basins in the southern part of the country (Ot'ahel'ová 1980, 1995a; Ot'ahel'ová \& al. 1985, 1994; Zlinská \& Kubalová 2001, Hrivnák 2002c). Ceratophyllum demersum overgrew the water reservoir Pláštovce (Fig. 2), where the mentioned dominant species created large, dense, submerged and species-poor stands. Association Ceratophylletum demersi frequently occurs in Slovakia (Otáahel'ová 1995a). Hrivnák (2002c) reported about the occurrence of Lemnetum minoris in

Figure 3: Stands of the Potametum natantis association in the water reservoir near Hrušovo village.

Slika 3: Sestoji asociacije Potametum natantis v vodnem zbiralniku v bližini vasi Hrušovo. 


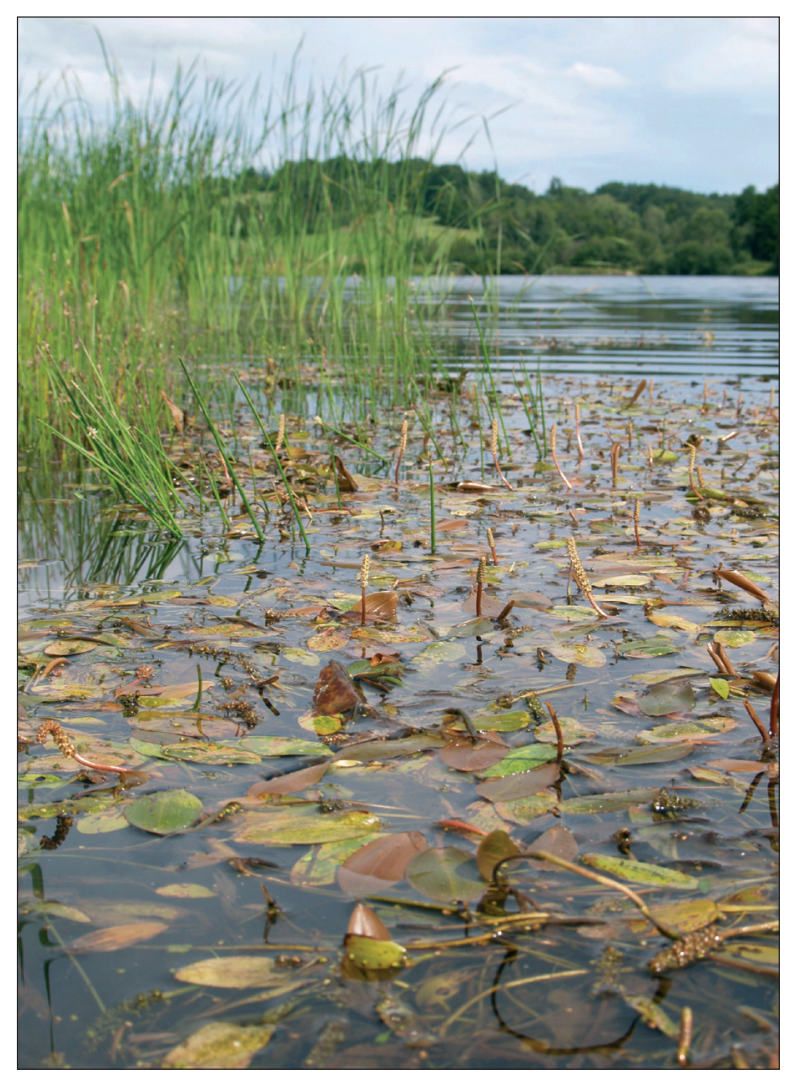

Figure 4: Stands of Potametum nodosi and Typhetum angustifoliae associations in the littoral of the Kosihovská Bukovina water reservoir.

Slika 4: Sestoji asociacij Potametum nodosi in Typhetum angustifoliae v obrežnem pasu vodnega zbiralnika Kosihovská Bukovina.

a water reservoir near the Hrušov village, which was not confirmed within recent research.

Regarding the diversity of the detected plant communities and number of relevés, the communities of the Potametea class were relatively better represented (Tab. 2). Stands with the dominance of species of the genus Potamogeton were mainly found. Among the broad-leaved species of this genus, $P$. natans was more frequent than $P$. nodosus. Potametum natantis (Fig. 3) created closed or moderately open stands in deeper waters. Dominant species of this community (P. natans) often grew also in other aquatic and marsh plant communities. On the territory of Slovakia, Potametum natantis is relatively frequent and occurs from the lowland up to the montane level (cf. Otahel'ová 1995b; Hrivnák 2002b; Hrivnák \& al. 2004, 2009). Potametum nodosi grew in the littoral of the water reservoir Kosihovská Bukovina (Fig. 4). Data about this community from Slovakia indicated its

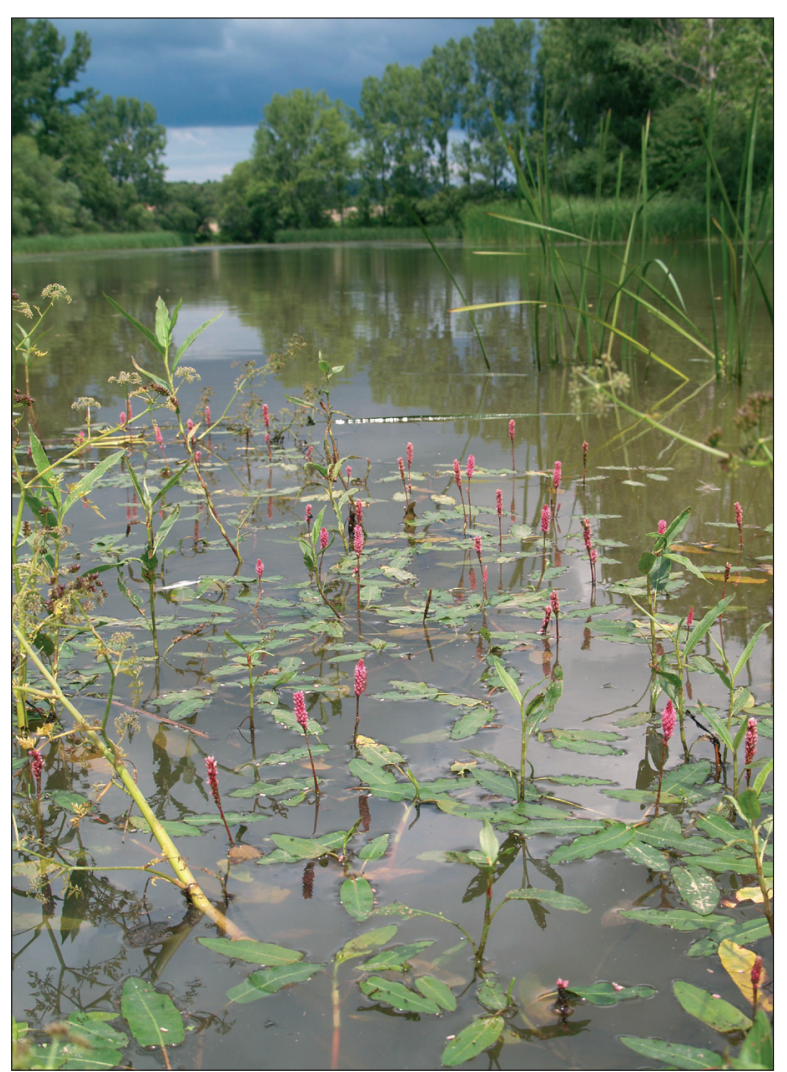

Figure 5: Stands of Polygonetum amphibii in the Velký Šiaš water reservoir.

Slika 5: Sestoji asociacije Polygonetum amphibii v vodnem rezervoarju Velký Šiaš.

occurrence mainly in running waters (Otahel'ová 1995b). The community is rare in stagnant waters (e.g. Ot'ahel'ová 2005), although the dominant species $P$. nodosus has an optimum of occurrence from stagnant to moderately flowing waters (Willby \& al. 2000). The last detected community from the Nymphaeion albae alliance is Polygonetum amphibii (Fig. 5). The association formed open and smaller stands in shallow to moderately deep waters. Among vegetation of the linear-leaved submerged species of the genus Potamogeton, Potametum pectinati, P. trichoidis and P. acutifolii associations were found, but their occurrence was relatively rare. Potametum pectinati formed larger stands in the water reservoir near Čekovce village, Potametum trichoidis occurred fragmentarily in the water reservoir Kozí Vrbovok. The former association occurs relatively often in Slovakia (cf. Otahel'ová 1995b). On the other hand, reports about the latter association are very rare (e.g. Háberová \& Karasová 
1991, Hrivnák 2002b, Kubalová 2009). Potametum acutifolii is a new community for the territory of Slovakia (cf. Otahel'ová 1995b, Jarolímek \& al. 2008). Stands of this community were found in the water reservoir near Hrušov village where it formed mosaic stands with Potametum natantis. In the Potametum natantis stand, Potamogeton acutifolius was found in the past (cf. Hrivnák 2002b). The dominant species $P$. acutifolius occurred in almost all plant communities within the reservoir (cf. Tab. 2 a 3). In addition to the mentioned dominant species, floating hydrophytes (Potamogeton natans and Lemna minor) in deeper water and helophytes in shallower water were detected in the stands of Potametum acutifolii (Tab. 2, rel. 11). The water was $70-100 \mathrm{~cm}$ deep, slightly alkaline with a relatively low content of soluble mineral matters (cf. Tab. 1) and with a high water transparency ( $95 \mathrm{~cm}$ measured by Secchi disk). The bottom was formed of fine material (silt-clay sediment). Low concentrations of ammonia ( 0.126 $\mathrm{mg} / \mathrm{l})$ and nitrites $(0.154 \mathrm{mg} / \mathrm{l})$, and slightly higher values of nitrates $(2.189 \mathrm{mg} / \mathrm{l})$ and phosphates $(1.328 \mathrm{mg} / \mathrm{l})$ in water were detected. In general, this community grows in small ponds, in shallow and eutrophic, neutral or alkaline water with various sediments on the bottom (Tomaszewicz 1979; Rydlo 2005, 2006; Nowak \& al. 2007). Stands are species-poor and in addition to dominant species $P$. acutifolius, various aquatic plants grow in stands of this community (Tomaszewicz 1979, Nowak \& al. 2007, Šumberová \& Hrivnák 2010). These facts are similar to those identified in the Krupinská planina Mts. Among Central European countries, the community rarely occurs in Poland (Matuszkiewicz 2001, Nowak \& al. 2007), the Czech Republic (Šumberová \& Hrivnák 2010) and Germany (Pott 1992). It is interesting that in the Czech Republic Potamogeton acutifolius is quite abundant (Kaplan 2001), but stands with its dominance are rare (Šumberová \& Hrivnák 2010).

The most diverse groups of the studied vegetation are the marsh communities, where 12 associations were detected. More than a half of them belong to typical littoral marsh communities of the Phragmition communis alliance. The most frequent are Typhetum latifoliae, T. angustifoliae and Sparganietum erecti. All are frequent not only in the studied area, but within the whole territory of Slovakia (Otahel'ová \& al. 2001). Species composition reflects the actual ecophase (sensu Hejný 1960): in addition to dominant species, true aquatic species (Lemna minor, Potamogeton spec. div.) grow in

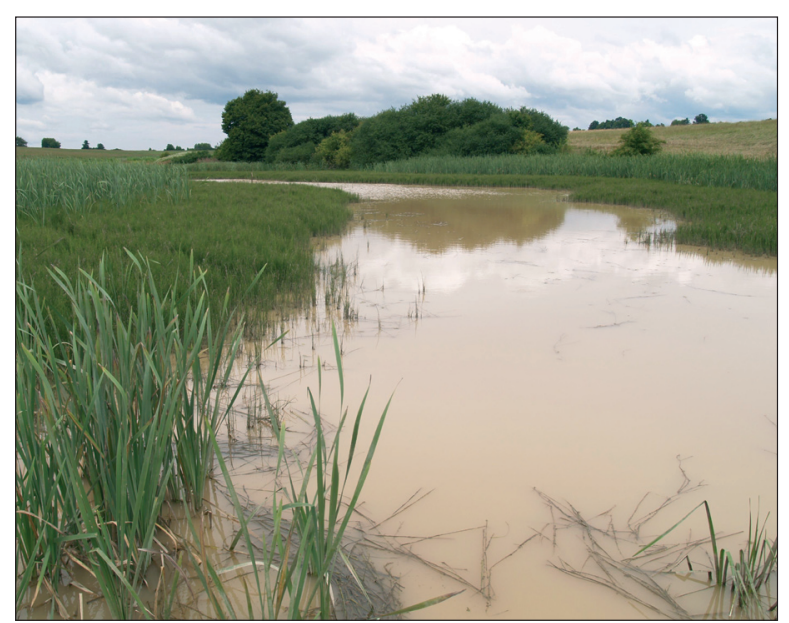

Figure 6: Water reservoir near Duchenec village with large stands of Equisetum limosi and Typhetum latifoliae in the littoral after strong rainfall.

Slika 6: Vodni zbiralnik pri vasi Duchenec z obsežnimi sestoji asociacij Equisetum limosi in Typhetum latifoliae v obrežnem pasu po obilnem deževju.

the littoral ecophase, the number of typical marsh species increases with a decrease of water level and species of eutrophic sediments such as Bidens spec. div., Persicaria hydropiper or Leersia oryzoides grow in the limose ecophase. Less frequent are the following 4 communities: Glycerietum aquaticae, Phragmitetum vulgaris, Scirpetum lacustris and Equisetetum limosi. Equisetetum limosi is interesting for its occurrence in water reservoirs near Duchenec (Fig. 6) and Riečky villages. This association has a borealsubatlantic distribution (Balátová-Tuláčková \& al. 1993) and in Slovakia it occurs from the upland to the montane levels and very rarely also in lowlands (cf. Ot́ahel'ová \& al. 2001). Accessible data about this association in Slovakia are relatively rare and data from phytogeographical region Ipel'skorimavská brázda are absent at present. The $M a g$ nocaricion elatae alliance is represented only by two associations, Caricetum vesicariae and Phalaridetum arundinaceae. Both of them are rare in the study area and the occurrence of the former one is fragmentary. Glycerietum fluitantis and Leersietum oryzoidis grew on silted and deep sediment within inflow parts of reservoirs. The water was shallow or sometimes only the sediment was waterlogged. Similar ecological characteristics were typical also for Eleocharitetum palustris, stands of which were found in the water reservoir of Kosihovská Bukovina from shallow to moderately deep water. The community survives well within disturbed habitats, too. Great water level fluctuation is typical 
for all three communities. Similar characteristics were reported from several European countries (e.g. Balátová-Tuláčková \& al. 1993, Coldea 1997, Ot'ahel'ová \& al. 2001, Stančič 2007).
Based on the Ellenbergs indicator values, I detected that the main environmental gradient is clearly the factor "Moisture" (Fig. 7). This factor correlates most closely with the first DCA axes

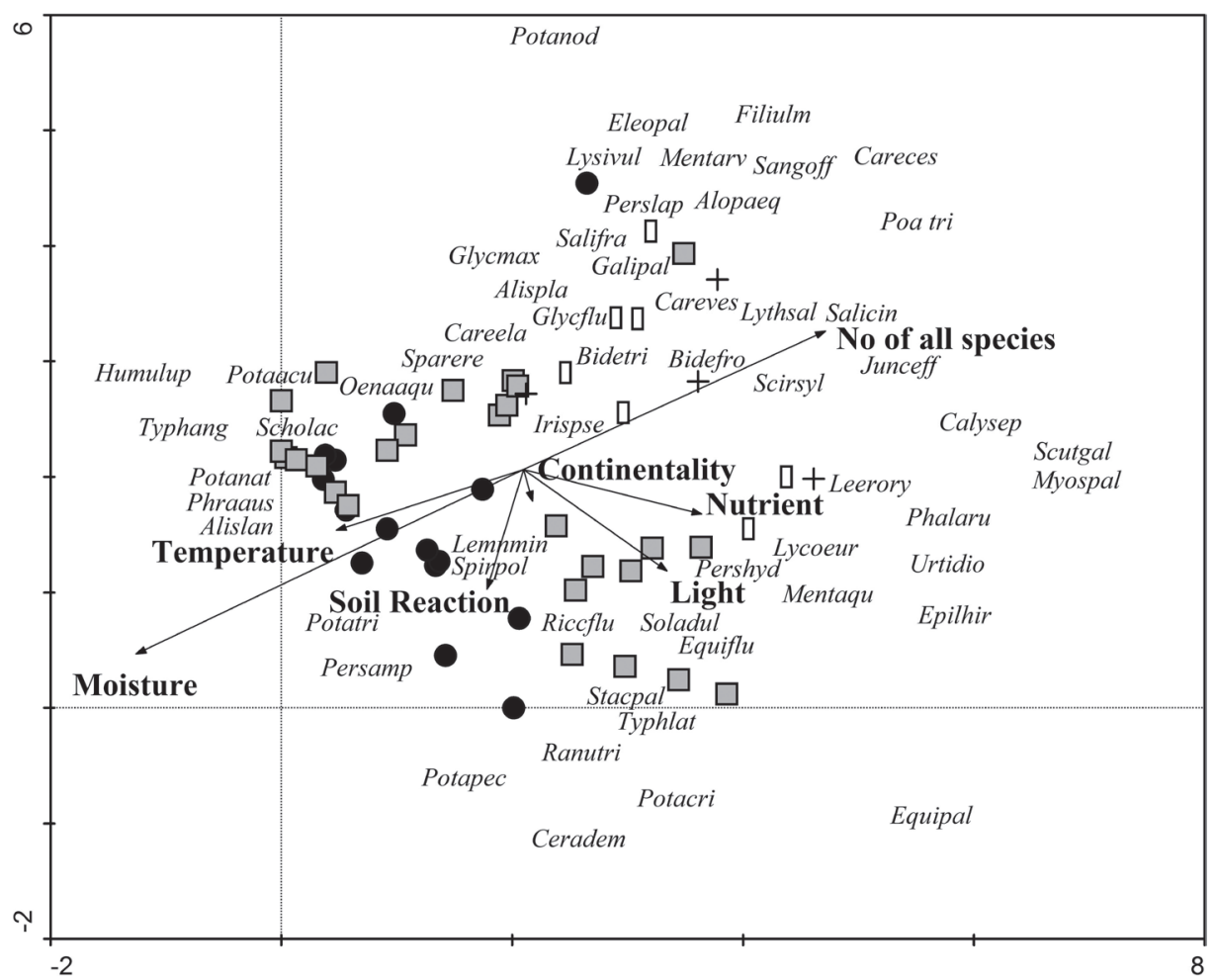

Figure 7: Ordination diagram of both species and sample data with supplementary environmental variables (Ellenberg indicator values) and number of species. Full circles - aquatic plant communities of the Lemnetea and Potametea classes, shaded squares - reed vegetation of the Phragmition communis alliance, empty rectangles - marsh vegetation of the Oenanthion aquaticae and Glycerio-Sparganion alliances, crosses - tall-sedges vegetation of the Magnocaricion alliance. The first two axes explain 15.3 and $32.0 \%$ of species variability and species-environment relation, respectively. Weighted correlations between first two axes and environmental variables: Light: 0.2907 and -0.1900 , Temperature: -0.3766 and -0.1107 , Continentality: 0.0184 and -0.0585 , Moisture: -0.7794 and -0.3385 , Soil reaction: -0.0721 and -0.2217 , Nutrients: 0.3599 and -0.0848 .

Slika 7: Ordinacijski diagram vrst in popisov z dodatnimi okoljskimi spremenljivkami (Ellenbergove indikacijske vrednosti) in število vrst. Polni krogi - vodne rastlinske združbe razredov Lemnetea in Potametea, zasenčeni kvadrati - trstje, ki ga uvrščamo v zvezo Phragmition communis, prazni pravokotniki - močvirna vegetacija zvez Oenanthion aquaticae in Glycerio-Sparganion, križi - visoko šašje, ki ga uvrščamo v zvezo Magnocaricion. Prvi dve osi pojasnita 15,3 in 32,0 \% vrstne variabilnosti oziroma odnosa rastlinske vrste - okolje. Tehtana korelacija med prvima dvema osema in okoljskimi spremenljivakami: svetloba: 0,2907 in $-0,1900$, toplota: $-0,3766$ in $-0,1107$, kontinentalnost: 0,0184 in $-0,0585$, vlažnost: $-0,7794$ in $-0,3385$, reakcija tal: $-0,0721$ in $-0,2217$, hranila: 0,3599 in $-0,0848$.

\footnotetext{
Abbreviations of species (Okrajšave vrst): Alislan - Alisma lanceolatum, Alispla - Alisma plantago-aquatica, Alopaeq - Alopecurus aequalis, Ranutri - Batrachium trichophyllum, Bidefro - Bidens frondosa, Bidetri - Bidens tripartitus, Calysep - Calystegia sepium, Careces - Carex cespitosa, Careela - Carex elata, Careves - Carex vesicaria, Ceradem - Ceratophyllum demerum, Eleopal - Eleocharis palustris, Epilhir - Epilobium hirsutum, Equiflu - Equisetum fluviatile, Equipal - Equisetum palustre, Filiulm - Filipendula ulmaria, Galipal - Galium palustre, Glycflu - Glyceria fluitans, Glycmax - Glyceria maxima, Humulup - Humulus lupulus, Irispse - Iris pseudacorus, Junceff - Juncus effusus, Leerory - Leersia oryzoides, Lemnmin - Lemna minor, Lycoeur - Lycopus europaeus, Lysyvul - Lysimachia vulgaris, Lythsal - Lythrum salicaria, Mentarv - Mentha arvenis, Mentaqu - Mentha aquatica, Myospal - Myosotis scorpioides agg., Persamp - Persicaria amphibia, Pershyd - Persicaria hydropiper, Perslap - Persicaria lapathifolia, Phalaru - Phalaroides arundinacea, Oenaaqu - Phellandrium aquaticum, Phraaus - Phragmites australis, Poa tri - Poa trivialis, Potaacu - Potamogeton acutifolius, Potacri - Potamogeton crispus, Potanat - Potamogeton natans, Potanod - Potamogeton nodosus, Potapec - Potamogeton pectinatus, Potatri - Potamogeton trichoides, Riccflu - Riccia fluitans, Sangoff - Sanguisorba officinalis, Salicin - Salix cinerea, Salifra - Salix fragilis, Scholac - Schoenoplectus lacustris, Scirsyl - Scirpus sylvaticus, Scutgal - Scutellaria galericulata, Soladul - Solanum dulcamara, Sparere - Sparganium erectum, Spirpol - Spirodella polyrhiza, Stacpal - Stachys palustris, Typhang - Typha angustifolia, Typhlat - Typha latifolia, Urtidio - Urtica dioica.
} 


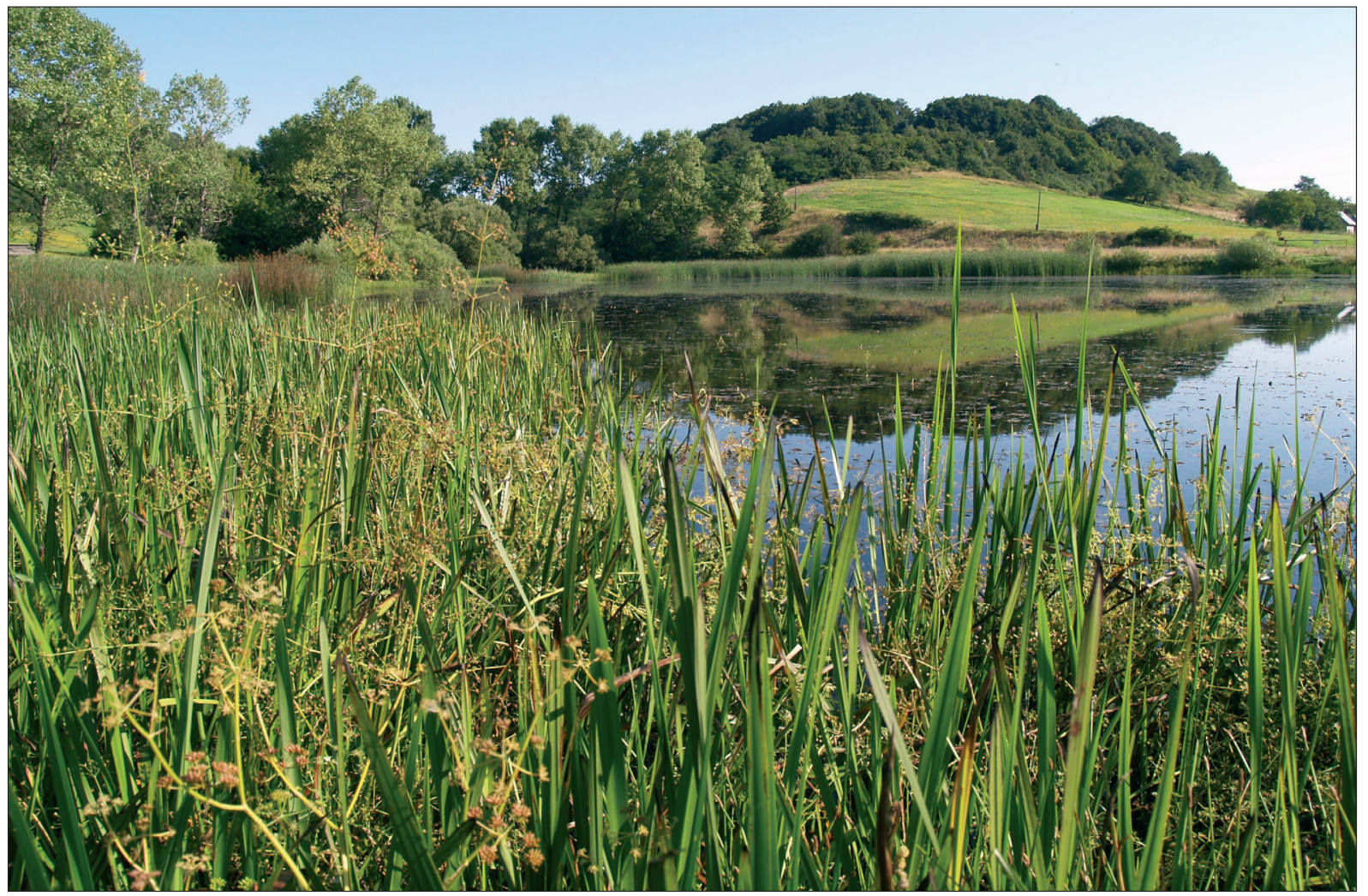

Figure 8: Water reservoir near Hrušov village with the most various macrophyte vegetation and with occurrence of the Potametum acutiformis association.

Slika 8: Vodni zbiralnik pri vasi Hrušov z najbolj raznoliko makrofitsko vegetacijo in spojavljanjem sestojev asociacije Potametum acutiformis.

(-0.78). Along the moisture gradient, individual communities were arranged more or less according to the natural hydrosere of habitats with stagnant water. From the left to the right side of the DCA ordination graph, aquatic communities of the Potametea class are the first displayed, followed by pleustophyte vegetation of the Lemnetea class and littoral communities of the Phragmition communis alliance and finished by marsh vegetation of shallow waters of the upper littoral of the Magnocaricion elatae, Sparganio-Glycerion and Oenanthion aquaticae alliances. True aquatic plants, such as species of the Potamogeton genera, Persicaria amphibia f. natans or some helophytes such as Phragmites australis, Schoenoplectus lacustris or Typha angustifolia (left side of Fig. 7) are typical for permanent and deeper waters. Wet meadow species (e.g. Poa trivialis, Myosotis scorpioides agg. or Funcus effusus), some nitrophilous, liana species or species of exposed substrates (e.g. Urtica dioica, Calystegia sepium and Alopecurus aequalis) are displayed on the other side of the moisture gradient (the right side of Fig. 7).
Species richness increases with decreasing water depth. The correlation between the number of species and water depth in individual relevés is statistically significant $(P<0.001)$, although the correlation coefficient is relatively low (Spearman's $r=-0.506)$. The same is indicated by Fig. 7, where a negative correlation between moisture and the number of species $(r=-0.555, P<0.001)$ is obvious. It is caused by the presence of true aquatic plants as well as marsh and wet meadow species in shallower waters, representing appropriate conditions for all species groups. Interaction between the size of individual reservoirs and number of detected plant communities is weak and non-significant $(r=0.436, P=0.1)$. Reservoirs with relatively small size can be rich in macrophyte vegetation (Hrušov; Fig. 8), in contrast to large reservoirs (Kozí Vrbovok; Tab. 1). Diversity of plant communities is probably influenced by the heterogeneity of environmental conditions, mainly in the littoral of reservoirs (e.g. type of substrate, reservoir profile, morphometrical characteristics). 


\subsection{Diversity of Vegetation in RELATION TO OTHER SlOVAK REgIONS}

Undoubtedly, Krupinská planina Mts. belongs to the areas with varying macrophyte vegetation of artificial water reservoirs. In general, the plant community diversity of reservoirs in the Pannonicum region is higher than within the Carpaticum. There are more suitable climatic conditions for development of macrophyte vegetation in the Pannonicum. For example, the following mean numbers of plant communities per artificial water reservoir were detected in individual Slovak regions: Pannonicum: Cerová vrchovina Mts almost 7 communities for reservoir (4 reservoirs were studied; Hrivnák \& Csiky 2009), Lučenská kotlina basin - more than 3 (10 reservoirs; Hrivnák 1999), Ipel'ská kotlina basin - more than 6 (4 reservoirs; Otahel'ová \& al. 1998, Hrivnák 1999), Borská nížina lowland - almost 3 (10 reservoirs; Otahel'ová 2005); Carpaticum: Zvolenská kotlina basin - more than 2 (5 reservoirs; Hrivnák 2002a), Nízke Tatry Mts - almost 2 (14 reservoirs; Hrivnák et al. 2009), Hornonitrianska kotlina basin - almost 3 (13 reservoirs; Dúbravková \& al. 2009), Vel'ká Fatra Mts and Turčianska kotlina basin - almost 2 (11 reservoirs; Hrivnák \& Kochjarová 2008). In the Krupinská planina Mts, more than 3 plant communities per reservoir were detected in 15 water reservoirs. The intermediate position of vegetation diversity in this area fully corresponds with the phytogeographical position of the studied region, which includes both Pannonicum and Carpaticum.

\subsection{COMPARISON OF MACROPHYTE COMMUNITY CHANGES}

Three artificial water reservoirs were chosen for a comparison of changes of macrophyte vegetation: Drienovo (in village; No. 4 in Table 1), Hrušov (6) and Cerovo, Vel'ký Śiaš (13). For these reservoirs, relatively the most detailed information about the studied vegetation types was available (Table 4). The most important changes were detected in the case of the first-mentioned reservoir (Drienovo). Three plant communities were found at this location in the past, but no community was detected during the recent research; only their fragments affected by strong human impact grew in the littoral of the reservoir (Fig. 9). The locality is situ-

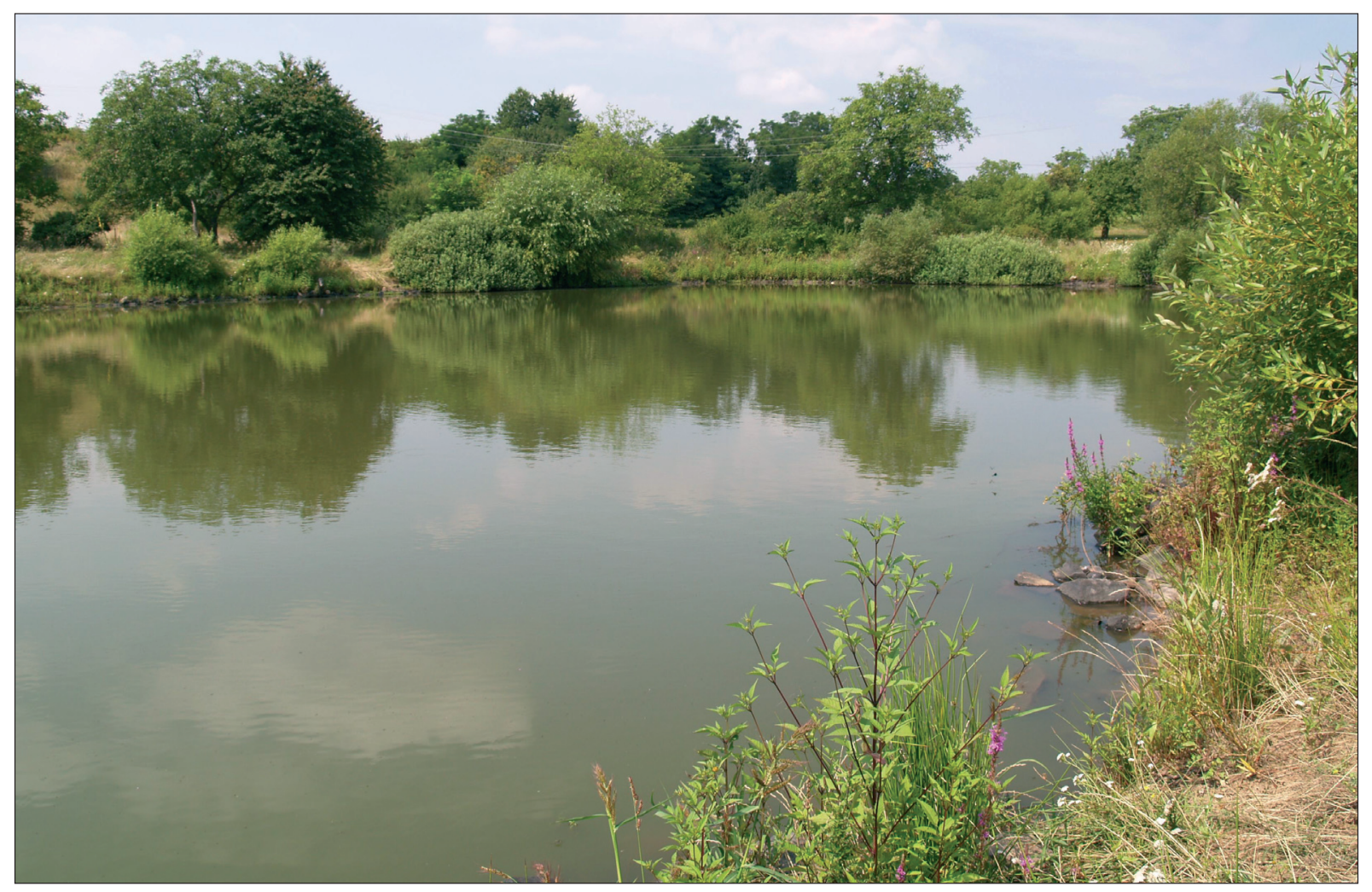

Figure 9: Water reservoirs in Drienovo village.

Slika 9: Vodni rezervoar v vasi Drienovo. 
ated on the margin of a village and the reservoir is used for many human activities. Vegetation in the littoral and on the banks is frequently mown during the vegetation period. All these activities inhibit development of littoral vegetation. Heavily eutrophic water is often overgrown by cyanophytes, which inhibits the development of aquatic vegetation as well. Within the second reservoir under study (Hrušov), no negative changes were determined. Only Eleocharitetum palustris was missing at present (mentioned in the 1990's; cf. Hrivnák 1999), but it may re-appear if the water level decreases. Individuals of Eleocharis palustris were frequent in the littoral of the reservoir, but they did not form larger stands. On the other hand, 6 new communities were found in the reservoir, which were not mentioned in the past. At the last locality (Vel'ký Šiaš), changes result from the difference in water level during studies in the past and in 2008. The occurrence of Typhetum angustifoliae and Potametum natantis was detected in the past as well as during the recent research, always during the period of more or less stable higher water level (cf. Hrivnák 2002b, 2004). The next two communities, Polygonetum amphibii and Lemnetum minoris were found in only one surveyed season. Both communities have a seasonal character, very often they grow fragmentarily and in dependence on various environmental conditions (Otahel'ová 1995a, b). Stands of Oenantho aquaticae-Rorippetum amphibiae and funcus bufonius comm. grew on the exposed bottom of the reservoir (cf. Hrivnák 1999). Water level increasing above the usual value was observed during recent research in 2008. Changes recorded in the three model reservoirs show that macrophyte vegetation of stagnant waters is very dynamic and affected by many environmental factors and human influence. Water level fluctuations as well as other disturbances belong to the most important factors affecting aquatic and marsh plants and their vegetation (Lacoul \& Freedman 2006).

\section{ACKNOWLEDGEMENTS}

I would like to thank my son Matúš for help during field work, Zdeněk Kaplan for revision of specimens of Potamogeton trichoides and P. acutifolius, Peter Pal'ove-Balang for chemical analysis, Dušan Senko for help with GIS, Helena Ot'ahel'ová and two anonymous reviewers for comments on the text. This work was supported by grant no. 2/0013/28 of the Grant Agency of the Ministry of Education and Slovak Academy of Sciences VEGA.

\section{REFERENCES}

Balátová-Tuláčková, E., Mucina, L., Ellmauer, T. \& Wallnöfer, S. 1993: Phragmiti-Magnocaricetea. In: Grabherr, G. \& Mucina, L. (eds.): Die Pflanzengesellschaften Österreichs. Teil II. Natürliche waldfreie Vegetation. Gustav Fischer Verlag, Jena, pp. 79-130.

Chytrý, M. \& Otýpková, Z. 2003: Plot sizes used for phytosociological sampling of European vegetation. Journal of Vegetation Science 14: 563-570.

Coldea, Ch. 1997: Les associations végétales de Roumanie. Tome 1. Les associations herbacées naturelles. Presses Universitaires de Gluj, 261 pp.

Dúbravková, D., Hrivnák, R. \& Otahel'ová, H. 2010: Makrofytná vegetácia Košských mokradí (stredné Slovensko). Bulletin Slovenskej Botanickej Spoločnosti 32 (accepted).

Ellenberg, H., Weber, H.E., Düll, R., Wirth, W., Werner, W. \& Paulißen, D. 1992: Zeigerwerte von Pflanzen in Mitteleuropa (2nd ed.). Scripta Geobotanica 18: 1-258.

Futák, J. 1980: Fytogeografické členenie. In: Mazúr, E. (ed): Atlas SSR. SAV, Bratislava \& Slovenský ústav geodézie a kartografie, Bratislava, p. 88, mapa VII/14.

Háberová, I. \& Karasová, E. 1991: Hydroséria vegetácie Jašteričieho jazera na Silickej planine. Ochrana Prírody 11: 298-307.

Hejný, S. 1960: Ökologische Charakteristik der Wasser- und Sumpflanzen in den slowakischen Tiefebenen, (Donau- und Theissgebiet). Vydavatel'stvo SAV, Bratislava, $492 \mathrm{pp}$.

Hennekens, S. M. \& Schaminée, J. H. J. 2001: TURBOVEG, a comprehensive data base management system for vegetation data. Journal of Vegetation Science 12: 589-591.

Hill, M. O. 1979: TWINSPAN. A Fortran program for arranging multivariate data in an ordered two-way table by classification of the individuals and attributes. Cornell Univ., Ithaca.

Hrivnák, R. 1999: Príspevok k poznaniu vegetácie niektorých antropogénnych vodných nádrží južnej časti stredného Slovenska. In: Urban, P. \& Bitušík, P. (eds): Príroda Krupinskej pla- 
niny a jej ochrana. SAŽP, Banská Bystrica, pp. 49-56.

Hrivnák, R. 2002a: Vodné a močiarne rastlinné spoločenstvá v povodí rieky Slatina (stredné Slovensko). Ochrana Prírody 21: 31-50.

Hrivnák, R. 2002b: Aquatic plant communities in the catchment area of the Ipel' river in Slovakia and Hungary. Part II. Class Potametea. Thaiszia - Journal of Botany 12: 137-160.

Hrivnák, R. 2002c: Aquatic plant communities in the catchment area of the Ipel' river in Slovakia and Hungary. Part I. Classes Lemnetea and Charetea fragilis. Thaiszia - Journal of Botany 12: 25-50.

Hrivnák, R. 2004: The plant communities of Phragmitetalia in the catchment area of the Ipel' river (Slovakia and Hungary) 1. Reed wetlands (Phragmition communis). Biologia 59: 73-97.

Hrivnák, R. \& Kochjarová, J. 2008: Rastlinné spoločenstvá vôd a močiarov Vel'kej Fatry a pril'ahlej časti Turčianskej kotliny. Bulletin Slovenskej Botanickej Spoločnosti 30: 261-270.

Hrivnák, R. \& Csiky, J. 2009: Aquatic and marsh plant communities of the Cerová vrchovina/ Cseres hegység Mts (Slovakia and Hungary). Thaiszia - Journal of Botany 19: 71-89.

Hrivnák, R., Blanár, D. \& Kochjarová, J. 2004: Vodné a močiarne rastlinné spoločenstvá $\mathrm{Mu}-$ ránskej planiny. Reussia 1: 33-54.

Hrivnák, R., Ot'ahel'ová, H., Kochjarová, J. \& Dúbravková, D. 2009: Makrofytná vegetácia vodných nádrží Nízkych Tatier (Slovensko). Bulletin Slovenskej Botanickej Spoločnosti 31 (2): $41-51$.

Jarolímek, I., Šibík, J., Hegedüšová, K., Janišová, M., Kliment, J., Kučera, P., Májeková, J., Michálková, D., Sadloňová, J., Šibíková, J., Škodová, I, Uhlířová, J., Ujházy, K., Ujházyová, M., Valachovič, M. \& Zaliberová, M. 2008: A list of vegetation units of Slovakia. In: Jarolímek, I. \& Šibík, J. (eds): Diagnostic, constant and dominant species of the higher vegetation units of Slovakia. Veda, Bratislava, pp. 295-329.

Jursa, M. \& Ot'ahel'ová, H. 2005: The distribution of aquatic macrophytes in man-modified waterbodies in the Danube river in Bratislava region (Slovakia). Ekológia 24: 368-384.

Kaplan, Z. 2001: Úzkolisté druhy rodu Potamogeton v květeně České republiky. II. P. compressus a P. acutifolius. Preslia 73: 127-139.

Kubalová, S. 2009: Vodná a močiarna vegetácia alúvia dolného Hrona (jz. Slovensko). Bulletin Slovenskej Botanickej Spoločnosti 31: 73-82.

Lacoul, P. \& B. Freedman, 2006: Environmental influences on aquatic plants in freshwater ecosystems. Environmental Reviews 14: 89-136.

Marhold, K. \& F. Hindák (eds) 1998: Zoznam nižších a vyšších rastlín Slovenska. Veda, Bratislava, $688 \mathrm{pp}$.

Matuszkiewicz, W. 2001: Przewodnik do oznaczania zbiorovisk roślinnych Polski. Wydawnictwo Naukowe PWN, Warszawa.

Miklós, L. (ed.) 2002: Atlas krajiny SR (1. vydanie). MŽP SR, Bratislava \& SAŽP, Banská Bystrica, $344 \mathrm{pp}$.

Nowak, A., Nowak, S. \& Czerniawska-Kusza, I. 2007: Rare and threatened pondweed communities in anthropogenic water bodies of Opole Silesia (SW Poland). Acta Societatis Botanicorum Poloniae 76: 151-163.

Ot'ahel'ová, H. 1980: Makrofytné spoločenstvá otvorených vôd Podunajskej roviny (trieda Lemnetea, Potamogetonetea). Biologické Práce Slovenskej Akadémie Vied 26: 3-180.

Otahel'ová, H. 1995a: Lemnetea de Bolós et Masclans 1955. In: Valachovič, M. (ed.): Rastlinné spoločenstvá Slovenska 1. Pionierska vegetácia. Veda, Bratislava, pp. 129-150.

Ot'ahel'ová, H. 1995b: Potametea R. Tx. et Preising 1942. In: Valachovič M. (ed.), Rastlinné spoločenstvá Slovenska 1. Pionierska vegetácia. Veda, Bratislava, pp.151-179.

Otahel'ová, H. 2005: Vodná makrofytná vegetácia štrkoviskových jazier na Borskej nížine. Bulletin Slovenskej Botanickej Spoločnosti 27: 151-156.

Otahel'ová, H. \& Husák, Š. 1982: Poznámky k vodnej a močiarnej vegetácii VSN. In: Špániková, A. (ed.): Vegetácia Východoslovenskej a Záhorskej nížiny. Acta Botanica Slovaca Acad. Sci. slovacae, Ser. A, 6: 125-148.

Otahel'ová, H. \& Husák, Š. 1992: Vegetácia odvodňovacích kanálov v okolí Gabčíkova-Slané jazero. Ochrana Prírody, Liptovský Mikuláš 1: 95-105.

Otahel'ová, H. \& Otahel', J. 2006: Distribution of aquatic macrophytes in pit lakes in relation to the environment (Borská nížina lowland, Slovakia). Ekológia 25: 398-411.

Otahelová, H., Husák, Š. \& Mucina, L. 1985: Vodná a močiarna vegetácia. In: Špániková A. (eds.): Vegetačné pomery južnej časti Východoslovenskej nížiny. Acta Botanica Slovaca Acad. Sci. slovacae, Ser.A, 8: 44-115. 
Ot'ahel'ová H., Janauer G. A. \&, Husák Š. 1994: Beitrag zur Wasser- und Sumpfvegetation Marchinundationsgebiet (Slowakei). - Ekológia, Bratislava, Suppl. 1: 43-54.

Ot'ahel'ová, H., Hrivnák, R., Valachovič, M. 1998: Sekundárna sukcesia litorálnej vegetácie antropogénnych nádrží v povodí Ipla a Slanej. In: Križová, E., Ujházy, K. (eds.): Sekundárna sukcesia II. Technická Univ., Zvolen, pp. $105-118$.

Ot'ahel'ová, H., Hrivnák, R. \& Valachovič, M. 2001: Phragmito-Magnocaricetea. In: Valachovič, M. (ed.): Rastlinné spoločenstvá Slovenska 3. Vegetácia mokradí, Veda, Bratislava, pp. 51-183.

Ot'ahel'ová, H., Hrivnák, R., Valachovič, M., Rydlo, J., Pal'ove-Balang, P. 2008: Vodná a močiarna vegetácia Národného parku Slovenský raj. Muzeum a současnost, Roztoky, ser. natur. 23: 148-163.

Pott, R. 1992: Die Pflanzengesellschaften Deutschlands. Verlag Eugen Ulmer, Stuttgart, 427 pp.

Rydlo, J., 2005: Vodní makrofyta ve stojatých vodách na Poděbradsku a Nymbursku. Muzeum a Současnost, ser. natur. 20: 11-134.

Rydlo, J., 2006: Vodní makrofyta ve stojatých vodách v brdských Hřebenech a v jejich podhůř́. Muzeum a Současnost, ser. natur., 21: 71-125.

Schratt, L. 1993: Lemnetea. In: Grabherr, G., Mucina, L. (eds.): Die Pflanzengesellschaften Österreichs. Teil II. Gustav Fischer Verlag, Jena, pp. $31-44$.

Stančić, Z. 2007: Marshland vegetation of the class Phragmito-Magnocaricetea in Croatia. Biologia 62: 297-314.
StatSoft 2001: 2001. STATISTICA. System reference. StatSoft Inc., Tulsa.

Šomšák, L. 1963: Močiarna vegetácia medzidunových zníženín južnej časti Potickej nížiny. Acta Facultatis Rerum Naturalium Universitatis Comenianae, Botanica 8: 229-302.

Šumberová, K. 2007: Vegetace tř́́dy Lemnetea v České republice - kolik toho o ní víme? Zpravy České Botanické Společnosti 42, Materiály 22: 5-17.

Šumberová, K. \& Hrivnák, R. 2010: Potametum acutifolii Segal 1961. In: Chytrý, M. (ed.): Vegetace České republiky 3. Vodní a mokřadní vegetace. Academia, Praha (ined.).

Tichý, L. 2002: JUICE, software for vegetation classification. Journal of Vegetation Science 13: 451-453.

ter Braak, C. J. F. \& Šmilauer, P. 2002: CANOCO Reference manual and CanoDraw for Windows User's guide. Software for Canonical Community Ordination (version 4.5). Microcomputer Power, Ithaca, NY.

Tomaszewicz, H. 1979: Rośliność wodna i szuwarowa Polski. Wydawnictva Uniwersytetu Warszawskiego, Warszawa, 325 pp.

Zlinská, J. \& Kubalová, S. 2001: Flóra a vegetácia lokality Gamota na Podunajskej nížine a ochrana jej biodiverzity. Acta Environmentalistica Universitatis Comenianae 11: 3-120.

Willby, N. J., Abernethy, V. J. \& Demars, B. O. L. 2000: Attribute-based classification of European hydrophytes and its relationship to habitat utilization. Freshwater Biology 43: 43-74. 


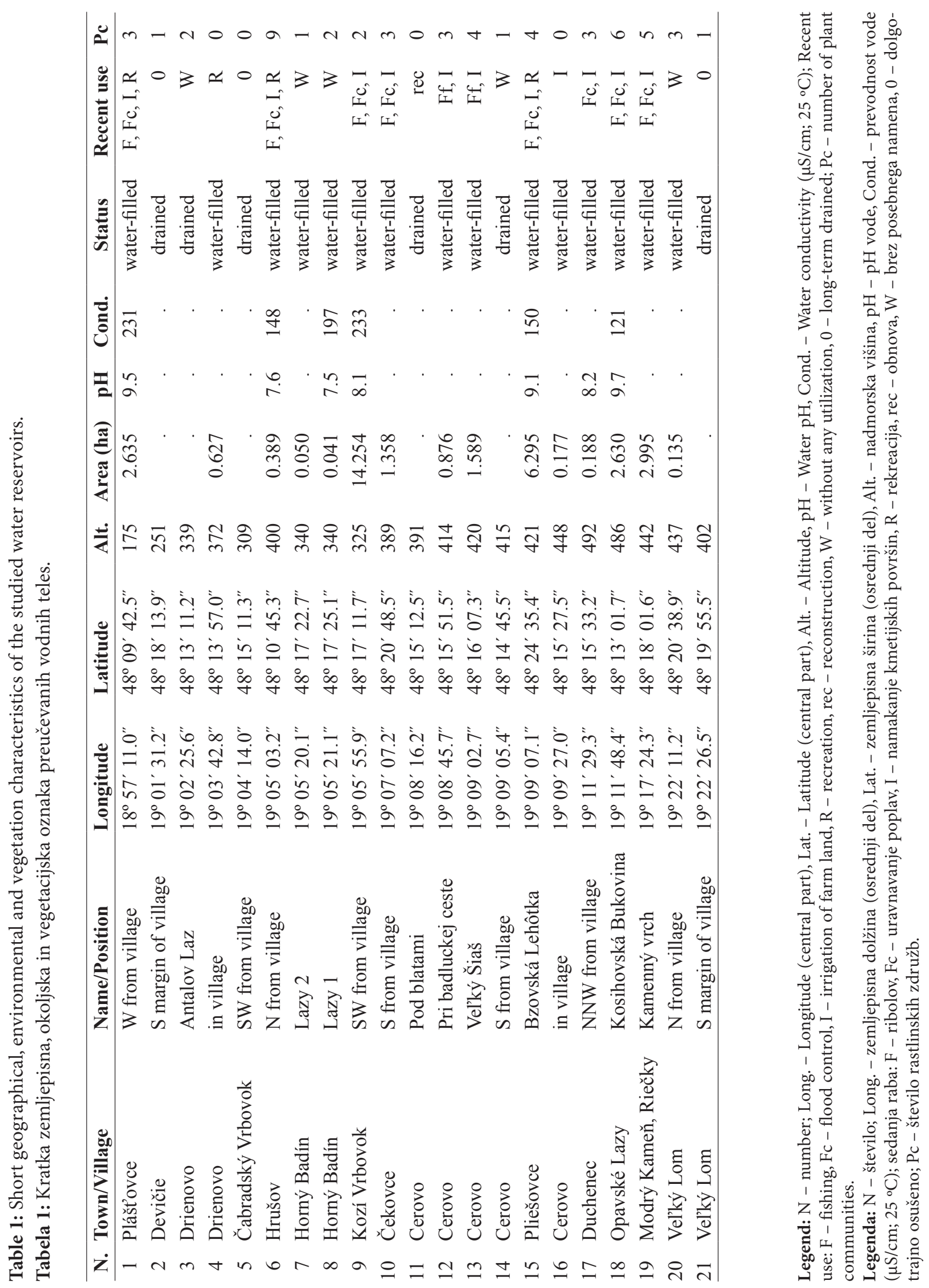


Table 2: Aquatic vegetation of the studied water reservoirs.

Tabela 2: Vodna vegetacija preučevanih vodnih zbiralnikov.

\begin{tabular}{|c|c|c|c|c|c|c|c|c|c|c|c|c|c|c|c|c|}
\hline \multirow[t]{6}{*}{$*$} & Relevé number & 1 & 2 & 3 & 4 & 5 & 6 & 7 & 8 & 9 & 10 & 11 & 12 & 13 & 14 & 15 \\
\hline & Water reservoir & 20 & 8 & 7 & 1 & 13 & 10 & 20 & 17 & 13 & 6 & 6 & 6 & 18 & 9 & 10 \\
\hline & Cover $(\%)$ & 98 & 100 & 95 & 100 & 55 & 90 & 80 & 50 & 95 & 95 & 100 & 100 & 75 & 95 & 80 \\
\hline & Relevé area $\left(\mathrm{m}^{2}\right)$ & 20 & 16 & 16 & 16 & 6 & 9 & 20 & 16 & 12 & 16 & 14 & 14 & 12 & 12 & 16 \\
\hline & Depth of water $(\mathrm{cm})$ & 40 & 10 & 10 & 100 & 55 & 90 & 100 & 150 & 80 & 105 & 80 & 100 & 80 & 45 & 115 \\
\hline & Sediment type & $\mathrm{F}$ & $\mathrm{F}$ & $\mathrm{F}$ & . & $\mathrm{F}$ & . & $\mathrm{F}$ & . & . & $\mathrm{F}$ & $\mathrm{F}$ & $\mathrm{F}$ & $\mathrm{F}$ & $\mathrm{S} / \mathrm{F}$ & . \\
\hline \multicolumn{17}{|c|}{ Dominant species of associations } \\
\hline Le & Lemna minor & 5 & 3 & 5 & + & . & $\mathrm{m}$ & $\mathrm{a}$ & . & . & + & 1 & 1 & . & a & + \\
\hline Le & Spirodela polyrhiza & + & 4 & b & . & . & . & . & . & . & . & . & . & . & . & . \\
\hline Le & Ceratophyllum demersum & . & . & . & 5 & . & . & . & . & . & . & . & . & . & . & . \\
\hline Po & Persicaria amphibia f. natans & . & . & . & . & 4 & 4 & . & . & . & . & . & . & . & . & . \\
\hline Po & Potamogeton natans & . & . & . & . & + & . & 4 & 3 & 5 & 5 & 3 & 3 & . & . & . \\
\hline Po & Potamogeton acutifolius & . & . & . & . & . & . & . & . & . & 1 & 4 & 5 & . & . & . \\
\hline Po & Potamogeton nodosus & . & . & . & . & . & . & . & . & . & . & . & . & 4 & . & . \\
\hline Po & Potamogeton trichoides & . & . & . & . & . & . & . & . & . & . & . & . & . & 5 & 1 \\
\hline & Potamogeton pectinatus & . & . & . & . & . & 1 & . & . & . & . & . & . & . & . & 4 \\
\hline \multicolumn{17}{|c|}{ Other species } \\
\hline Pm & Glyceria fluitans & + & . & . & . & . & . & . & . & . & . & + & . & $\mathrm{r}$ & . & . \\
\hline Pm & Phellandrium aquaticum & . & . & . & . & $\mathrm{r}$ & . & . & . & . & . & $\mathrm{a}$ & . & . & + & . \\
\hline Pm & Alisma plantago-aquatica & $\mathrm{r}$ & . & . & . & . & . & . & . & . & . & . & . & 1 & . & . \\
\hline Pm & Eleocharis palustris & . & . & . & . & . & . & . & . & . & . & + & . & 1 & . & . \\
\hline
\end{tabular}

Legend: * Le - Lemnetea, Po - Potametea, Pm - Phragmito-Magnocaricetea; full headers with higher accuracy location of individual relevés are presented in the Slovak national phytosociological database (http://ibot.sav.sk/cdf/index.html).

Sediment type: $\mathrm{F}$ - anorganic or organic fine sediment, $\mathrm{S}$ - stone or artificial block sediment.

Species only in one relevé (Vrste samo v enem popisu): Alisma lanceolatum (7: +), Batrachium trichophyllum (14: r), Carex vesicaria (11: 1), Equisetum fluviatile (8: 1), Lycopus europaeus (6: +), Salix fragilis (1: r), Sparganium erectum (9: +), Typha latifolia $(6:+)$.

Legenda: ${ }^{*}$ Le - Lemnetea, Po - Potametea, Pm - Phragmito-Magnocaricetea; celotna glava popisov z večjo natančnostjo lokacije je shranjena v Slovaški nacionalni fitocenološki podatkovni bazi (http://ibot.sav.sk/cdf/index.html).

Tip sedimenta: F - anorganski ali organski fini sediment, S - kamenje ali umetni kamniti sediment.

Table 3: $\rightarrow$

Full headers with higher accuracy location of individual relevés are presented in the Slovak national phytosociological database (http://ibot.sav.sk/cdf/index.html).

Celotna glava popisov z večjo natančnostjo lokacije je shranjena v Slovaški nacionalni fitocenološki podatkovni bazi (http:// ibot.sav.sk/cdf/index.html). 
Table 3: Marsh vegetation of the studied water reservoirs.

Table 3: Močvirna vegetacija preučevanih vodnih zbiralnikov.

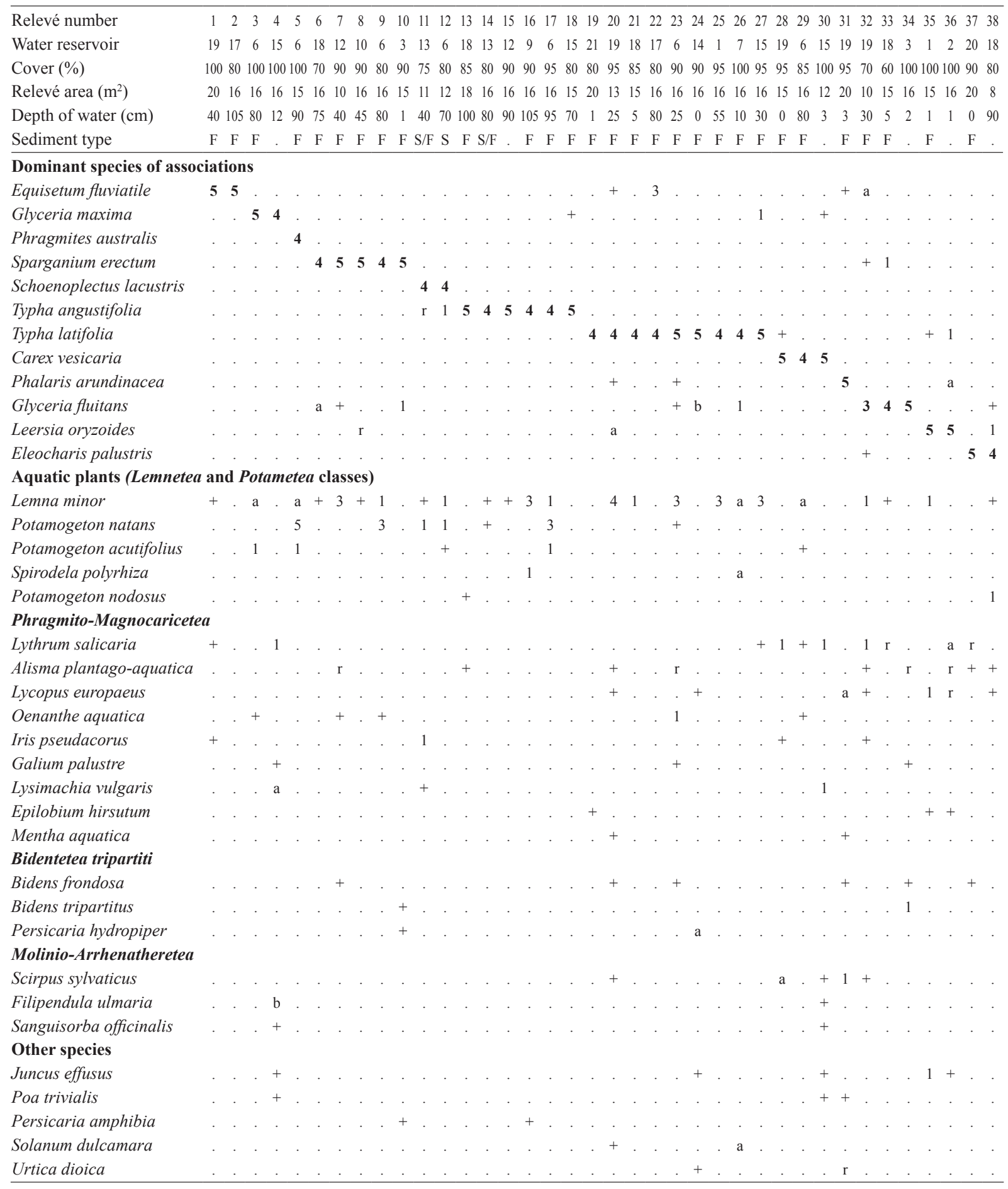

Species in one relevé only (Vrste samo v enem popisu): Alopecurus aequalis (34: a), Batrachium trichophyllum (21: 1), Calystegia sepium (36: +), Carex cespitosa (30:+), Carex elata (29: 1), Ceratophyllum demersum (25:3), Equisetum palustre (19: a), Humulus lupulus (18: +), Mentha arvensis (38: +), Myosotis scorpioides agg. (31: +), Persicaria lapathifolia (34: +), Potamogeton crispus (21: +), Riccia fluitans (27: b), Salix cinerea (28: +), Salix fragilis (37: r), Scutellaria galericulata (31: +), Stachys palustris (1: r). 
Table 4: Comparison of plant communities changes within the three selected artificial water reservoirs.

Table 4: Primerjava spremembe rastlinskih združb v treh izbranih umetnih vodnih zbiralnikih.

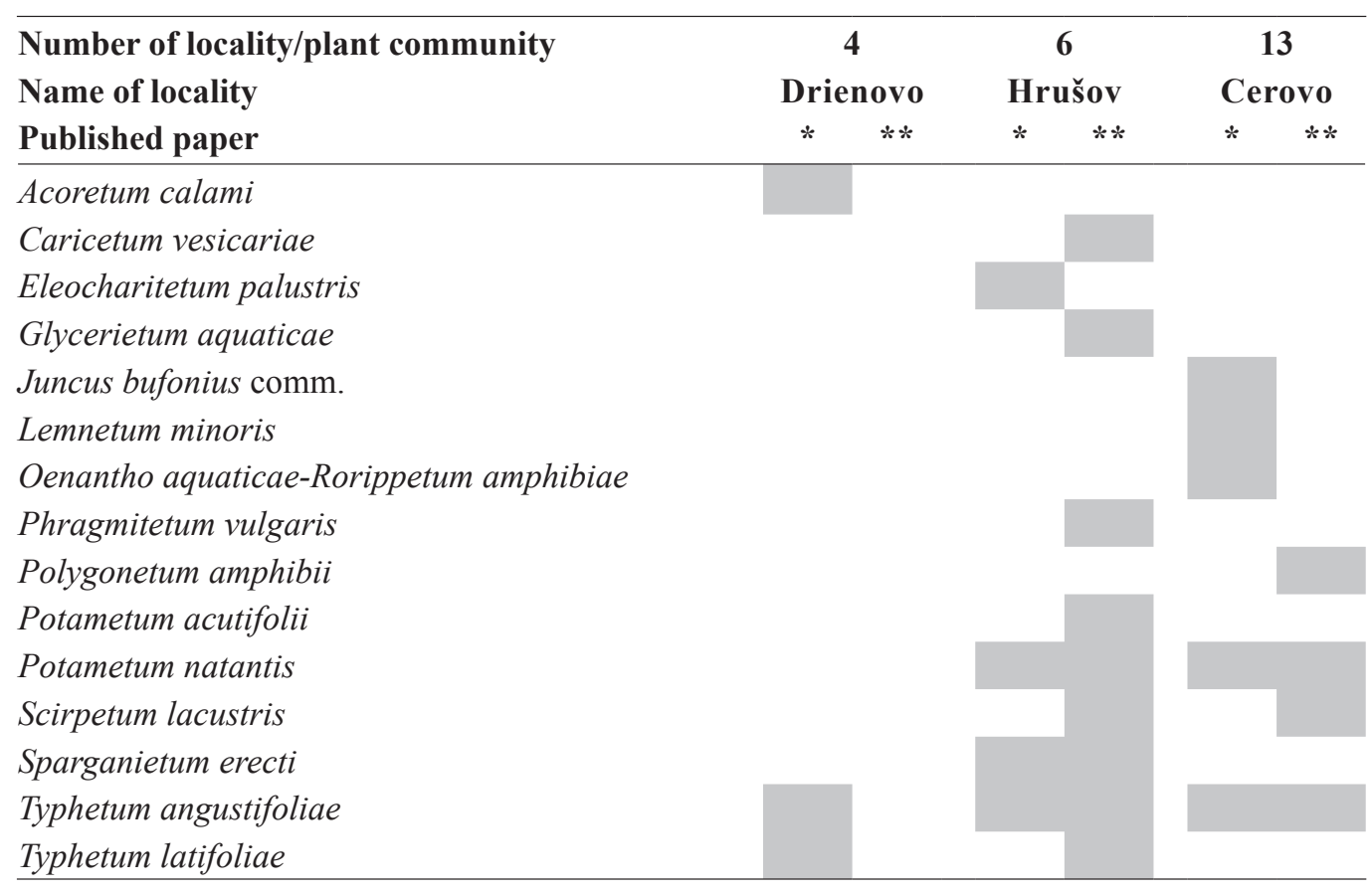

${ }^{\star}$ Earlier papers - Hrivnák (1999; 2002a, b; 2004), ${ }^{* *}$ this paper.

*Starejše objave - Hrivnák (1999; 2002a, b; 2004), ${ }^{* *} \mathrm{v}$ tem delu. 